\title{
Anna Zachorowska-Mazurkiewicz*
}

Jagiellonian University

ORCID: 0000-0003-4313-5207

\section{Magdalena Szyndera-Soltysik**}

Aptiv Krakow

\section{DOES TIME ALLOCATION MATTER \\ IN PROMOTION DECISIONS? - \\ A CASE STUDY OF WOMEN MANAGERS \\ IN APTIV KRAKOW TECH CENTER}

\begin{abstract}
Each day people make decisions regarding work-life balance, and these decisions impact many aspects of their lives, including career paths. In our article we point towards the relation between time and professional careers. There are more men than women in higher managerial positions and we inquire if time allocation matters when men and women choose to accept promotion or not. We start with a literature review regarding these issues, followed by empirical studies. The empirical studies have a twofold character. First, we conduct analysis of time-use data, and then we present the case study of managers in Aptiv Krakow Tech Center. As a result of the conducted studies, it seems that time is a constraint especially for women, although in terms of the stories of individual managers it is not evident as a universal barrier.
\end{abstract}

Keywords: time allocation, gender, promotion decisions, barriers to promotion

Both women and men participate in the labour market, although their activities differ. One distinctive feature is the feminization and masculinization of certain professions, as well as job positions. The gap resulting from having fewer women in managerial positions is often described in literature by metaphors such as 'glass ceiling' or 'sticky floor', suggesting that there are barriers constraining women from reaching top levels in management. Our paper aims to consider one of these barriers, namely time allocation.

* Corresponding author: Anna Zachorowska-Mazurkiewicz, Uniwersytet Jagielloński, Wydział Zarzadzania i Komunikacji Społecznej, Instytut Ekonomii, Finansów i Zarzadzania, ul. Łojasiewicza 4, 30-348 Kraków, e-mail: anna.zachorowska@uj.edu.pl.

** Corresponding author: Magdalena Szyndera-Sołtysik, Aptiv, ul. Podgórki Tynieckie 2, 30-399 Kraków, e-mail: magda.szyndera@aptiv.com. 
Time is a barrier because nowadays it seems to be scarcer than money. Each day people make decisions regarding work-life balance, and these decisions impact many aspects of their lives, including career paths. In our paper we point towards the relation between time and professional career. We begin with a literature review regarding time, gender and managerial positions, and then we turn to empirical studies, looking at time allocation in Poland disaggregating time-use data according to gender, age and level of education. This part is followed by a case study of women managers in Aptiv Krakow Tech Center. In this company decision makers were puzzled by the gender gap at the higher managerial level. They decided to engage in research to look for answers and potential solutions. The case study is followed by discussion and conclusions.

\section{TIME AS A BARRIER TO WOMEN'S PARTICIPATION IN THE LABOUR MARKET}

Although recent years have seen dramatic rises in women's labour-market participation rates in Western countries, there has also been constancy in the gender division of time devoted to work. Hochschild (1989) uses the term 'stalled revolution' to describe the situation, in which a higher women's employment rate is not followed by an increase in men's responsibility for domestic work. It is predominately women's time that is stretched between work in the unpaid and paid economies. The term 'second shift' has been used to describe the phenomena of increasing numbers of women who are income earners, yet at the same time continue to perform their traditional roles as household managers and care providers (Lynch, Baker and Lyons 2009: 19). This active role both at home and in the labour market produces the so-called 'dual burden' for women (Anxo et al. 2007: 1).

One possible explanation for this phenomenon is that men and women make choices about how to allocate their time, but their choices are considerably constrained by social relations and social inequalities (Sirianni and Negrey 2000: 59). Women more often than men perform unpaid work for their households, which takes many forms: cleaning, washing, cooking, gardening, and caring for children or adults. Men engage more in paid work conducted in the market. The entry and participation of women in the labour market and other sectors of the economy depends on the time they allocate to unpaid household work. Most men do not need to make such a connection. Such an unequal division of domestic work has been regarded as the reason for the unfavourable situation of women in the labour market (Humphries 1998: 223). This inequality limits women's opportunities to take up paid employment, limits productivity of labour, and decreases future global production in national economies. As it was noticed by the World Bank (1995: 4) the limitations women face regarding full-time, satisfying employment result from unequal division of unpaid work in households, which in turn is the effect of norms and values present in the society and in the labour market. The labour market is not an example of a fair game where all participants have equal chances, since women enter the game with the burden of household duties. It is not only a matter of time to perform paid work, but women have also less time for numerous activities that can strengthen their position in labour market, such as training, trade union membership, and taking full-time jobs. The model of employment requires continuity and full engagement, 
and it is very often impossible for women to fulfil such requirements. Thus, unequal gender division of labour explains women's limited opportunities, but also their long hours of work when they decide to take up paid employment (Esquivel 2011: 226).

Research on time allocation in households of married couples shows that no matter which methodology is used for calculations, most of the household work is performed by women, including those with full-time paid jobs (Sirianni and Negrey 2000: 61). Women who live with men continue to undertake, on average, twice the amount of unpaid work in the home as their partners. When there are children in the household, the ratio of women's to men's unpaid labour rises sharply, and this occurs independently of women's engagement in paid work (Hewitson 2003: 266; Folbre and Nelson 2000: 125; Titkow, Duch-Krzysztofek and Budrowska 2003). Similar analyses of time allocation in non-western countries were also conducted, and results found in Hirway (2010) and Esquivel, Budlender, Folbre and Hirway (2011) present a similar picture. It could be assumed that modern women are expected to be engaged in paid work and continue to perform their traditional duties at home (McDowell 2001). This explains concepts like 'second shift', or 'dual burden', mentioned earlier in the text.

Differences in time allocation occurring between men and women vary remarkably along the life course (Anxo et al. 2007: 1). The presence of children always increases specialization within the household (Bonke et al. 2007, cited in Pasqua, Mancini 2012). Pasqua and Mancini (2012) describe the problem of time allocation in Italy, and Anxo et al. (2007) in Italy, France, Sweden and the United States. In 2015 Zachorowska-Mazurkiewicz and Mroczek conducted studies of time allocation between different activities by women and men in Poland. The study was based on time-use data gathered in Poland in 2003 and 2004. Again, as in previous cases the dual burden of work experienced by women was obvious. Many of the most vigorous pressures and key promotion stages occur during childbearing years, thus disadvantaging those who interrupt their careers. These are predominantly mothers who decrease their working time or even exit the labour market, while men typically increase the time they devote to paid work (Anxo et al. 2007: 1; Wóycicka 2009: 107). Anxo et al. (2007) state that the experience of parenthood often implies a crystallization of gender roles, and that is why it is important to investigate the allocation of time in the contexts of both gender and life-cycle.

Many studies note that work hours tend to be especially long in professional and managerial occupations (Jacobs and Gerson 2004; Kuhn and Lozano 2008, cited in Cha 2013: 160). People in managerial jobs have an average work week of 50 hours in OECD countries (Simpson 1998), which is 16 hours more than the average employee within that group (OECD 2015) (cited in Brockmann et al. 2018: 760). In many professional and managerial jobs, work hours are considered a proxy for workers' commitment or professional competence: those who are present at work for long hours are believed to be more committed (Cha 2010: 304). Thus, when people have the opportunity to take up a leadership position, they trade a lot of money for a lot of time, but as indicated above, women and men face different monetary and time constraints, particularly in the household context (Brockmann et al. 2018: 759). Marriage and parenthood influence women's time use far more than men's (Pasqua and Mancini 2012), and hence they restrain women's careers to a far larger extent than men's. Family responsibilities still fall disproportionately on women, even when they occupy top leadership positions (Moore 2004, cited in Brockmann 2018: 761). Linehan and Walsh (2000, cited in Brockmann et al. 2018: 761) interviewed 50 female international senior managers and found that, regardless 
of how many hours women work in their jobs, they still take the primary responsibility for childbearing and household tasks.

Women are underrepresented in leadership positions, even in the most developed societies. One possible explanation is the double burden of work. Among the arguments explaining this global phenomenon, Brockmann et al. (2018: 756) enumerate discriminating structures as well as discriminating individuals, but also the fact that women in leadership positions are not as satisfied or happy as men in the same position, and that women's life satisfaction does not increase with occupying high executive positions. Interestingly, they write that such a substantial difference in life satisfaction usually shows no gender bias among the overall population. Human decisions, including career decisions, are generally based on happinessseeking and satisfaction-seeking strategies (Hsee et al. 2008, cited in Brockmann 2018). As mentioned above, a leadership position requires a huge time commitment, and managers have to trade money and status for spare and family time (Cha 2010,2013). The substitution of time for money translates into the decision for or against a certain job, and this decision is not made in a vacuum (Brockmann et al. 2018: 756).

Brockmann et al. (2018: 774) write that to boost the number of women in leading positions, we should first understand why women are less satisfied with their careers than their male counterparts. They verify three hypotheses: (1) women are less happy in managerial jobs than men as they face a biologically restricted reproduction regime that is difficult to reconcile with the timing of a conventional managerial career, (2) women are less happy in managerial jobs then men because they value career and family differently than men, and (3) women are less happy in managerial jobs than men because they have to trade off more spare/family time for less income. They found that time is a decisive factor in the first hypothesis, due to women's biology, particularly terminable fecundity, and in the third one due to the micro-management of daily schedules. However, they did not find empirical support for the selectivity of female managers with respect to gendered preferences (hypothesis 2). Regarding such time constraints Brockmann et al. conclude that "as long as pathways into leadership positions require a non-stop lifelong commitment to extra-long working hours and early career path-dependencies, many women with their higher appreciation of disposable time particularly at younger ages will be scared away from these positions" (775).

Time is a variable likely to influence many career-related choices. Time is critically involved in decisions about how best to sequence childbirth, care for children, and work. In light of this it would be valuable to include time as a dimension in career decision-making studies and to understand ways in which the delay associated with the timing of outcomes influences choice (Hesketh 2000: 63). In the following sections, we first look at time constraints faced by women in Poland, based on time-use data. Then we turn to individual stories in the case study conducted in Aptiv Krakow Tech Center.

\section{ALLOCATION OF TIME BETWEEN PAID AND UNPAID ACTIVITIES IN POLAND}

Time is often scarcer than money, and its use affects many spheres of personal, family, and professional life (CSO 2015: 34). Research on time allocation is based on time-use 
studies. Time-use data make it possible to show how work performed outside the marketplace represents an essential and distinctive part of national economies and to highlight how this work is unevenly distributed among women and men (Gálvez-Muñoz, Rodríguez-Monroño and Domínguez-Serrano 2011: 125). Time-use studies are a theoretical construct that serves to measure the distribution of time among different activities. The first test time-use study in Poland was conducted by the Institute of Social Economy in 1927. After the Second World War, research into the distribution of time in Poland was conducted by the Central Statistical Office (CSO) in 1969. The sample used in the research was not representative for the whole nation, since the research was conducted mainly in cities (Hozer-Koćmiel 2010: 72). Subsequent research was conducted by the CSO in 1976, 1984 and 2003/2004.

The last set of data was collected between 1 January and 31 December 2013 and published in 2016. A survey was conducted on a representative sample of 28,209 households. It covered more than 40,000 persons aged 10 and up. Selected households completed the survey for two days - one weekday and one weekend day. The respondents recorded performed activities, main and secondary, describing them freely in fixed 10-minute time intervals, entering persons accompanying them when they were performing those activities (CSO 2015: 34-35).

Data collected from the survey bear information regarding distribution of time among eleven different categories: (1) personal care, (2) employment, (3) study, (4) household and family time, (5) voluntary work, (6) social life and entertainment, (7) sport and outdoor activities, (8) hobbies and games, (9) mass media, (10) travel, and (11) unspecified time use. These may be organized in bigger groups, such as obligation time (aggregating data regarding employment, study, household and family care, and voluntary work), and leisure time (aggregating data regarding social life and entertainment, hobbies and games, mass media, and sport and outdoor activities). Distribution of time depends on characteristics like gender, age and education. Figures 1-3 present the distribution of time dependent on these characteristics.

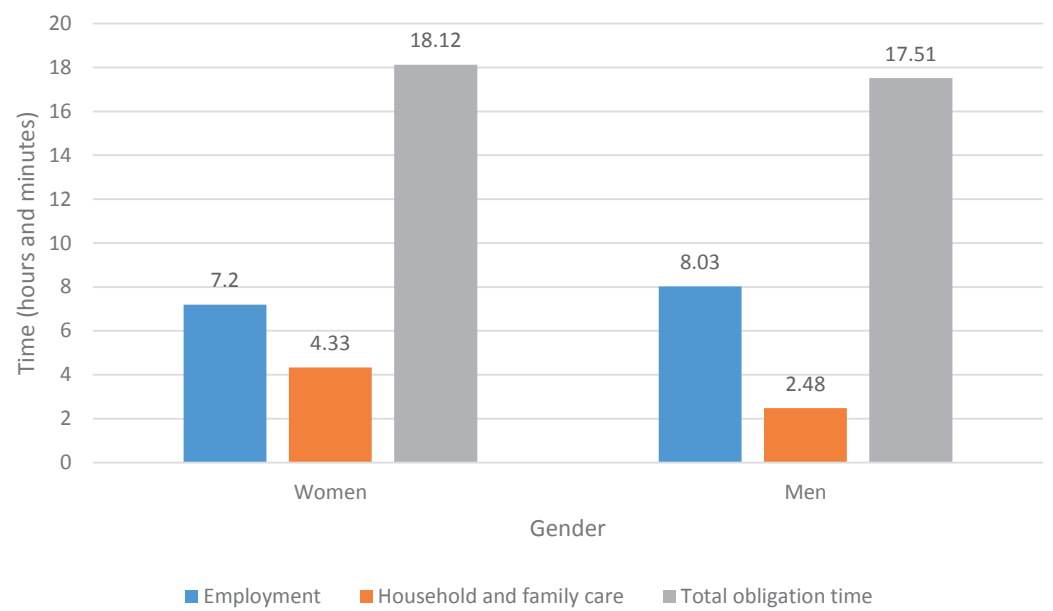

Figure 1. Average time of activity performance by gender (in hours and minutes)

Source: own elaboration based on CSO 2015, Table 1 
Women on average devote more time in total to obligations than men every day (18 hours 12 minutes, compared to 17 hours and 51 minutes). The daily difference of 21 minutes adds up to almost 2.5 hours per week ( 2 hours and 27 minutes). Such a difference is due to greater engagement of women in household and family care, since men are more involved in employment. Men devote an hour more to paid employment every day, while women almost two hours more to household and family care. It seems that in Poland, like in other developed economies, working women bear a double burden of work.

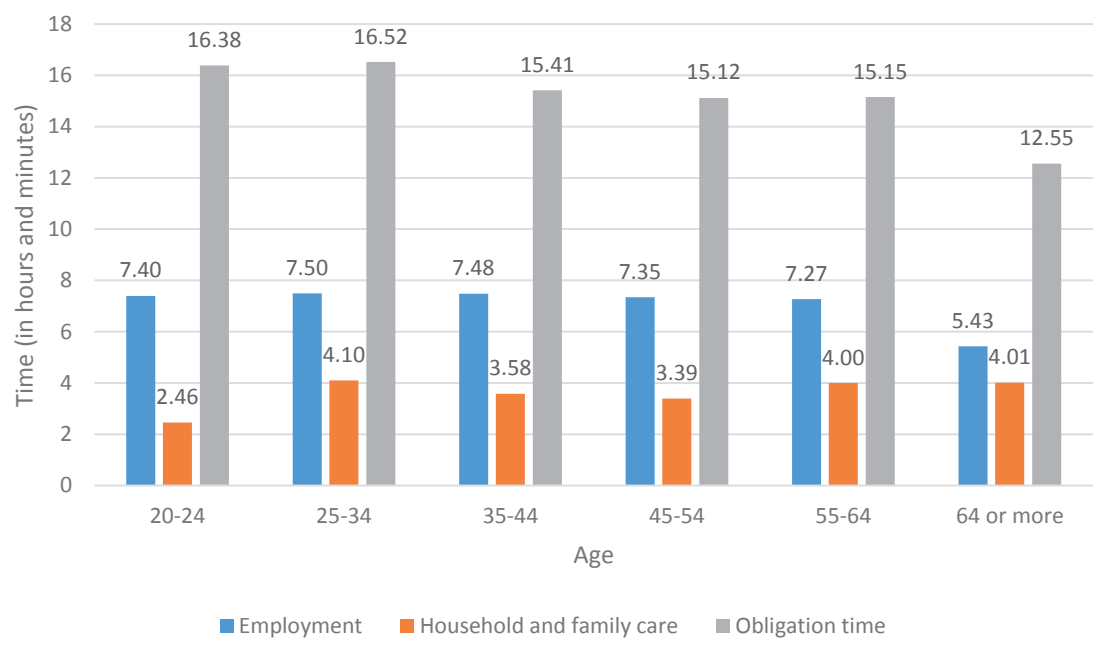

Figure 2. Average time of activity performance by age group (in hours and minutes)

Source: own elaboration based on CSO 2015, Table 3

As shown in Figure 2, age is also crucial when it comes to time distribution. Time devoted to performing obligatory activities increases until it reaches its peak between 25-34 years of age. Time devoted to employment increases until it reaches its peak in this particular age group, and then it starts to decrease steadily. Interestingly, time devoted to care changes in a slightly different way. It reaches its peak in the 25-34 year-old age group, then it declines but not significantly (only by 31 minutes), and then it starts to increase again. So, it seems that time matters not only in terms of everyday allocation, but also within a life-cycle.

As shown in Figure 3, the level of education also influences the distribution of time. People with university diplomas (higher levels of education) work the fewest hours (16 hours and 7 minutes). They engage less in both paid employment and household and family care. People with secondary education engage in paid employment most out of all the education groups, while people with basic vocational training engage most in household and family care. At higher managerial levels people with university diplomas are usually considered. Regarding time, it seems that there are some time reserves ready to be used in case of promotion. 
Does time allocation matter in promotion decisions?

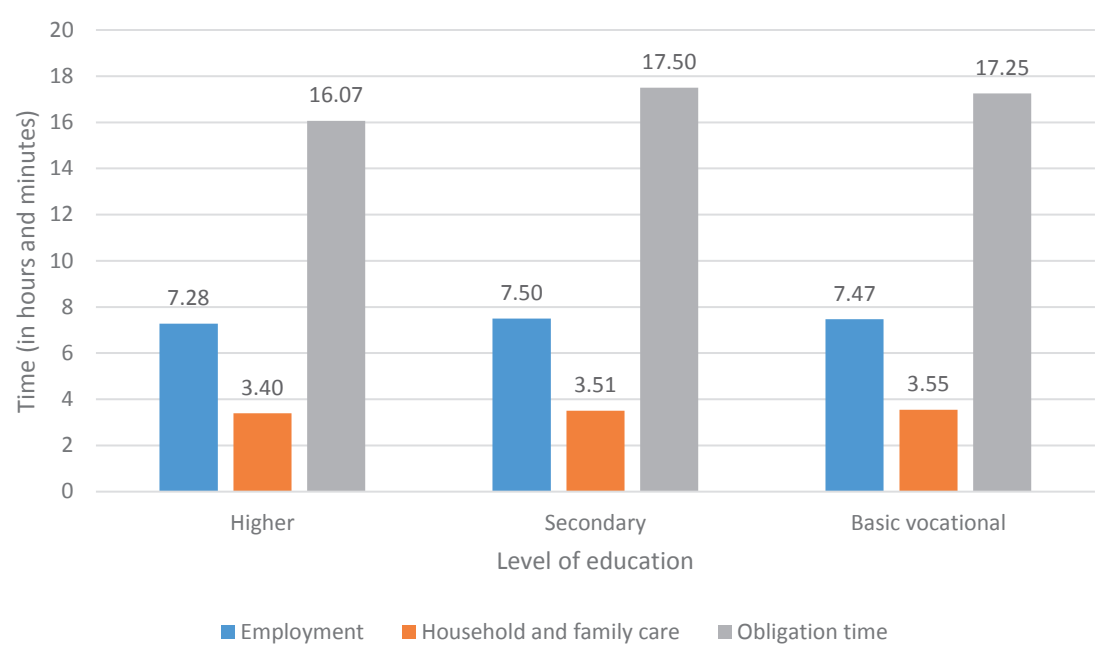

Figure 3. Average time of activity performance by level of education (in hours and minutes)

Source: own elaboration based on CSO 2015, Table 4

The comparison of time-use studies from 2003/4 and 2014 shows that even though the way people distribute time does not change significantly, there are trends that bear interesting information. Table 1 presents changes in time use by women and men observed between the last two surveys.

Table 1. Average time of activity performance - comparison between 2003/2004 and 2013 (in hours and minutes)

\begin{tabular}{|l|c|c|c|c|c|c|c|c|c|}
\cline { 2 - 10 } & \multicolumn{4}{|c|}{ Employment } & \multicolumn{3}{c|}{$\begin{array}{c}\text { Household and family } \\
\text { care }\end{array}$} & \multicolumn{3}{c|}{ Obligation time } \\
\cline { 2 - 11 } & $\mathbf{2 0 0 3 / 4}$ & $\mathbf{2 0 1 3}$ & $\boldsymbol{\Delta}$ & $\mathbf{2 0 0 3 / 4}$ & $\mathbf{2 0 1 3}$ & $\boldsymbol{\Delta}$ & $\mathbf{2 0 0 3 / 4}$ & $\mathbf{2 0 1 3}$ & $\Delta$ \\
\hline Women & 6.23 & 7.02 & +0.39 & 4.30 & 4.33 & +0.03 & 17.16 & 18.12 & +0.56 \\
\hline Men & 7.39 & 8.03 & +0.24 & 2.36 & 2.48 & +0.12 & 17.08 & 17.51 & +0.39 \\
\hline
\end{tabular}

Source: own elaboration based on CSO 2015, Table 10

Data presented in Table 1 show that obligation time is increasing, especially for women. Within 10 years women increased their obligation time almost by one hour, and the majority of that increase is linked to paid employment. In the case of men, obligation time has also increased, but slightly less than among women, by 39 minutes. Such a disproportion between women and men translates into an increase in time inequality - women used to spend 8 more minutes daily than men on different obligations in 2003/4, and in 2013 they were spending 21 minutes more. 
In such circumstances the question arises whether women are willing to take up additional responsibilities in the form of managerial jobs in corporations. Such jobs are linked to responsibility as well as an additional time burden. To analyse decisions regarding promotion and time it is not enough to look at data. The perspectives of people involved in decision making are also important. Aptiv in Krakow, formerly Delphi, was ready to become involved in such research, looking for the answer to the puzzle of why there are so few women in higher managerial positions. In order to analyse the internal situation of the company another methodology was adopted. The case study described in the next section covering the whole process is presented by one of the persons who initiated it.

\section{CASE STUDY OF APTIV KRAKOW TECH CENTER}

The case study of women managers in Aptiv Krakow is not typical research designed by external researchers to answer some universal research questions. It is instead a description of the internal process adopted in the company to understand the mechanism behind one of the problems the company has struggled with - the underrepresentation of women in higher managerial positions, as observed in Krakow. It is therefore impossible to present rigorous methodology used in this search for knowledge, it is rather a presentation of steps taken by decision-makers in Aptiv to solve the puzzle they encountered. This story began about two years ago.

An internal discussion was started in Aptiv (formerly Delphi) in Krakow to take actions to understand why they had fewer women in managerial positions. These kinds of discussions are constantly on-going in the market, not only in Aptiv. Nevertheless, the decision-makers in the company wanted to conduct some measurable, fact-based analysis to understand the root cause. At this stage, the discussion began, followed by cooperation with Diversity Hub organization. The first step proposed was to organize a discussion panel that took place at Aptiv. Diversity Hub invited HR representatives from selected companies and from universities and arranged a focus group discussion with the main topic of potential barriers that women can face in the business environment. Based on that meeting, a $4 \times 4$ model was proposed: a map to show different barriers that women can face during their professional career development $^{1}$. A list of external and internal barriers was later drawn up, which showed how they can influence each other and interact. An important outcome of these discussions is the fact that the company's environment is only one of the factors that can create obstacles or support. It is important to talk about that and plan courses of action to create equal approaches, but we cannot neglect other aspects, such as private environments and individual approaches.

After discussions with people involved in the process and based on results from the reviewed research it was even more obvious that private and professional time cannot be treated separately. These areas are overlapping, and "time" could be treated as a "budget" that is allocated between different activities. These observations needed to be verified, and the need to search for any repeatable factors that helped or withheld women from taking up

1 More on $4 \times 4$ model could be found in Zaroda-Dąbrowska and Dąbrowski work (2018). 
managerial positions was obvious. Based on that, it was decided to conduct interviews with a few selected women who hold managerial positions in Aptiv Krakow. Six women from the company were selected to take part in meetings. The Aptiv HR person responsible for internal communication and employer branding ran individual interviews, during which she asked each person these four questions:

- What was the turning point for you in your career development?

- Did you have any expectations from the company - any support you wanted to obtain? If yes - what kind? Did the company meet your expectations?

- What emotions do you remember from the moment you received an offer of promotion? What helped you to accept promotion?

- What were you afraid of when taking the decision about promotion?

After consolidating the results, it became obvious that the same conversations with a few selected male managers should be conducted to see if there are any similarities or differences. Four male managers were selected for interviews, and the same procedure was implemented. The answers were later analyzed to search for any general trends or similar approaches. Again, to no great surprise, each situation was highly individual. There are many factors influencing each particular situation and each case was different. There were, however, a few elements that we could observe and treat as general information. These elements are described below.

1. A turning point can be:

- a situation from professional life, i.e. positive - graduation or completing the first big project, but also those which can be perceived at the beginning as negative but later bringing new energy or motivation - first mistakes or failures;

- a situation from private life - e.g. divorce, childbirth.

2. Time can be perceived as:

- a period needed to think over priorities, analyse all pros and cons of the situation;

- verification - in most of the cases a few months are needed to see if our visions are close to reality;

- dedication to one part of our life, i.e. focus on professional development for some time, or choosing a less demanding job to be able to focus on family for some time.

3. Wrong assumptions - this can be the trickiest part. Each of us has some theories about a situation and believes to know a solution. We should be careful when we believe we know what someone thinks and needs. The most typical example could be a situation where an employer assumes that a young mother does not want to travel, and so does not even propose such a possibility. The most important outcome we took away from all these exercises were: 'the best way to get to know is simply to ask'.

4. Asking for help - very often this is not popular and has negative connotations. Individuals are afraid of showing weakness and perceive asking for help as such. We should try to promote the perception that asking for support is evidence of a willingness to learn, openness to suggestions and ideas, and readiness to develop. 
The main purpose of this brief analysis was to determine if the company should plan any special initiatives supporting the female part of the organization. It is a very broad topic and there are many different potential solutions and programs, which are driven by the needs of a particular company. In case of Aptiv Krakow, the company has offered different benefits for its employees. There is also an ongoing process in the company to verify whether and what additional actions can be implemented to support employees. Some examples of employees' benefits from Krakow are private health care, a child fund, life insurance, and an Employee Pension Plan. The company pays a lot of attention to diversity and inclusion, organizing many discussions around that. It promotes a culture of equal opportunities regardless of the sex and other characteristics of the employee. If one universal rule could be established based on studies conducted, it would be to create a "fair ground" for both women and men. In many of the discussions, women repeated: 'we don't need any special treatment only because of our sex'. Individual treatment is needed for every employee, not only for female employees, and in Aptiv attempts have been made to create such conditions.

\section{DISCUSSION AND CONCLUSIONS}

The analysis of time-use data for Poland confirms several phenomena and trends described in the literature. First, the comparison of two time-use datasets confirm that the stalled revolution described by Hochschild (1989) is also taking place in Poland, with women being more involved in the labour market than men are in household duties. Such inequality leads to a phenomenon which Lynch, Baker and Lyons (2009) call 'the second shift'. Polish women participating in the labour market are burdened by a second shift when they return home from work, like their counterparts in other countries. The majority of household and family work is performed by women. Some of the unpaid activities performed by women at home are linked to care, first care for the children, but since allocation of time to care does not decrease with aging, it comes to involve caring for other family members as well.

The amount of time spent on obligation peaks in one's 30s; it is also linked to family formation. This is also the time of launching professional careers. Since the time of family and career formation overlap, it puts additional pressure on women in managerial positions (Brockmann 2018). The individual cases analyzed in Aptiv Krakow point to turning points that were the inspiration to accept a promotion. Not surprisingly, since work and family time overlap, some turning points were situations from private lives. These individual stories also mentioned the time that was required after accepting a promotion.

As the next step, interviews covering a sample of managers that decided not to accept promotion can be considered. It is likely that time constraints, either concerning the life-cycle or distribution of time between paid and unpaid obligations, will appear as an answer to the question about the reasons to take such a decision. So far, the most important outcome of the interviews conducted is that each decision is an individual story of a particular person, and 
there are not many universal rules to be applied. Further studies could shed some more light on connections between promotion decisions and allocation of time.

\section{REFERENCES}

Anxo, Dominique, Lennart Flood, Letizia Mencarini, Ariane Pailhé, Anne Solaz and Maria Letizia Tanturri. 2007. Time Allocation between Work and Family over the Life-Cycle: A Comparative Gender Analysis of Italy, France, Sweden and the United States, IZA Discussion Papers No. 3193.

Bonke, Jens, Mette Deding, Mette Lausten and Leslie S. Stratton. 2008. Intrahousehold Specialization in Housework in the United States and Denmark, "Social Science Quarterly", 89, 4: 1023-1043.

Brockmann, Hilke, Anne-Maren Koch, Adele Diederich and Christofer Edling. 2018. Why Managerial Women are Less Happy Than Managerial Men, "Journal of Happiness Studies", 19: 755-779.

Central Statistical Office. 2015. Time Use Survey 2013, Warszawa.

Cha, Youngjoo. 2010. Reinforcing Separate Spheres: The Effect of Spousal Overwork on Men's and Women's Employment in Dual-Earner Households, "American Sociological Review", 75, 2: 303-329.

Cha, Youngjoo. 2013. Overwork and the persistence of gender segregation in occupations, "Gender \& Society", 27, 2: 158-184.

Esquivel, Valeria. 2011. Sixteen Years After Beijing: What Are New Policy Agendas for TimeUse Data Collection?, "Feminist Economics", 17, 4: 215-238.

Esquivel, Valeria, Debbie Budlender Nancy Folbre and Indira Hirway. 2008. Explorations: Time Use Surveys in the South, "Feminist Economics", 14, 3: 107-152.

Folbre, Nancy and Julie A. Nelson. 2000. For Love or Money - or Both?, "Journal of economic perspectives", 14, 4: 123-140.

Gálvez-Muñoz, Lina, Paula Rodríguez-Monroño and Mónica Domínguez-Serrano. 2011. Work and Time Use by Gender: A New Clustering of European Welfare Systems, "Feminist Economics", 17, 2: 125-157.

Hesketh, Beryl. 2000. Time Perspective in Career-Related Choices: Application of TimeDiscounting Principles, "Journal of Vocational Behavior", 57: 62-84.

Hewitson, Gillian J. 2003. Domestic labour and gender identity: are all women carers?, in: Drucilla K. Barker and Edith Kuiper (ed.), Towards a Feminist Philosophy of Economics, London - New York: Routledge, pp. 266-284.

Hirway, Indira. 2010. Time Use Surveys in Developing Countries: An Assessment, in: Rania Antonopoulos and Indira Hirway (ed.), Unpaid Work and the Economy: Gender, Time Use and Poverty in Developing Countries. Basingstoke: Palgrave MacMillan, pp. 252-324.

Hochschild, Arlie. 1989. The second shift. Working parents and the revolution at home, New York: Viking. 
Hozer-Koćmiel, Marta. 2010. Statystyczna analiza podziału czasu i wartości pracy kobiet, in: Wybrane zagadnienia gospodarowania i zarzadzania w pracach doktorskich obronionych na Wydziale Nauk Ekonomicznych i Zarzadzania, "Studia i Prace Wydziału Nauk Ekonomicznych i Zarządzania”, 20, Szczecin: Wydawnictwo Uniwersytetu Szczecińskiego, pp. 69-84.

Hsee, Christopher K., Reid Hastie and Jingqiu Chen. 2008. Hedonomics: Bridging decision research with happiness research, "Perspectives on Psychological Science", 3, 3: 224-243.

Humphries, Jane. 1998. Towards a Family-Friendly Economics, "New Political Economy", 3, 2: 223-240.

Jacobs, Jerry A. and Kathleen Gerson. 2004. The time divide: Work, family, and gender inequality, Cambridge, MA: Harvard University Press.

Kuhn, Peter and Ferdinando Lozano. 2008. The expanding workweek? Understanding trends in long work hours among U.S. men, 1979-2006, "Journal of Labor Economics", 26: 11-43.

Linehan, Margaret and James S. Walsh. 2000. Work-family conflict and the senior female international manager, "British Journal of Management", 11, Special Issue: S49-S58.

Lynch, Kathleen, John Baker and Maureen Lyons. 2009. Affective Equality: Love, Care and Injustice, Basingstoke: Palgrave MacMillan.

McDowell, Linda. 2001. Father and Ford revisited: gender, class and employment change in the new millennium, "Transactions of the Institute of British Geographers", 26, 4: 448-464.

Moore, Gwen. 2004. Mommies and daddies on the fast track in other wealthy nations, "The Annals of the American Academy of Political and Social Sciences", 596, 1: 208-213.

OECD. 2015. OECD Employment Outlook 2015, Paris: OECD Publishing.

Pasqua, Silvia and Anna Laura Mancini. 2012. Asymmetries and interdependencies in time use between Italian parents, "Applied Economics", 44, 32: 4153-4171.

Simpson, Ruth. 1998. Presenteeism, power, and organizational change: long hours as a career barrier and the impact on the working lives of women managers, "British Journal of Management", 9, Special Issue: 37-50.

Sirianni, Carmen and Cynthia Negrey. 2000. Working Time as Gendered Time, "Feminist Economics", 6, 1: 59-76.

Titkow, Anna, Danuta Duch-Krzysztofek and Bogusława Budrowska. 2003. Niepłatna praca kobiet - mity, realia, perspektywy, Warszawa: IFiS PAN.

World Bank. 1995. Towards Gender Equality. The Role of Public Policy, Washington D.C.

Wóycicka, Irena. 2009. Model opieki w Polsce, in: Irena E. Kotowska (ed.), Strukturalne i kulturowe uwarunkowania aktywności zawodowej kobiet w Polsce, Warszawa: Scholar, pp. 99-117.

Zachorowska-Mazurkiewicz, Anna and Katarzyna Mroczek. 2015. Time Allocation and the Life Cycle of Women and Men in Poland, in: Susan Moore (ed.), Contemporary Global Perspectives on Gender Economics, Hershey: IGI Global, pp. 292-313.

Zaroda-Dąbrowska, Anna and Tomasz Dąbrowski. 2018. Kobieta i kariera. Analiza barier w awansie kobiet liderek, "Personel Plus", 1: 72-77. 


\section{CZY ALOKACJA CZASU MA ZNACZENIE PRZY PODEJMOWANIU DECYZJI O AWANSIE? STUDIUM PRZYPADKU KOBIET MENEDŻEREK W CENTRUM TECHNICZNYM APTIV KRAKÓW}

Każdego dnia ludzie podejmują decyzje związane z równoważeniem życia zawodowego i prywatnego. Decyzje te wpływają na wiele aspektów ich życia, włączając w to ścieżki kariery zawodowej. W artykule wskazano powiązania między alokacją czasu a karierą zawodową. Mężczyźni stanowią większość wśród osób zatrudnionych na wysokich stanowiskach menedżerskich, a w prezentowanym opracowaniu staramy się dociec, czy alokacja czasu ma znaczenie przy przyjmowaniu propozycji awansu zawodowego przez kobiety i mężczyzn. Nasze rozważania rozpoczynamy przeglądem literatury dotyczącej alokacji czasu i zatrudnienia, ze szczególnym uwzględnieniem zatrudnienia na stanowiskach menedżerskich. Następnie omawiamy badania empiryczne, które miały dwojaki charakter. Najpierw zaprezentowana została analiza danych pochodzących z badania budżetu czasu, a następnie studium przypadku menedżerów zatrudnionych w krakowskim centrum technicznym Aptiv. Głównym wnioskiem nasuwającym się w wyniku przeprowadzonych badań jest to, że alokacja czasu wydaje się barierą głównie dla kobiet. Jednak warto również zwrócić uwagę, że w indywidualnych historiach menedżerów z Aptiv nie pojawia się ona jako bariera uniwersalna.

Słowa kluczowe: alokacja czasu, kobiety i mężczyźni, awans zawodowy, bariery ścieżki kariery zawodowej 